NASA/TM-1999-206575

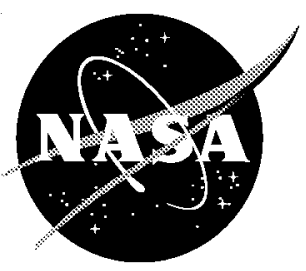

\title{
A Base Drag Reduction Experiment on the X-33 Linear Aerospike SR-71 Experiment (LASRE) Flight Program
}

Stephen A. Whitmore and Timothy R. Moes

Dryden Flight Research Center

Edwards, California 


\section{The NASA STI Program Office ... in Profile}

Since its founding, NASA has been dedicated to the advancement of aeronautics and space science. The NASA Scientific and Technical Information (STI) Program Office plays a key part in helping NASA maintain this important role.

The NASA STI Program Office is operated by Langley Research Center, the lead center for NASA's scientific and technical information. The NASA STI Program Office provides access to the NASA STI Database, the largest collection of aeronautical and space science STI in the world. The Program Office is also NASA's institutional mechanism for disseminating the results of its research and development activities. These results are published by NASA in the NASA STI Report Series, which includes the following report types:

- TECHNICAL PUBLICATION. Reports of completed research or a major significant phase of research that present the results of NASA programs and include extensive data or theoretical analysis. Includes compilations of significant scientific and technical data and information deemed to be of continuing reference value. NASA's counterpart of peer-reviewed formal professional papers but has less stringent limitations on manuscript length and extent of graphic presentations.

- TECHNICAL MEMORANDUM. Scientific and technical findings that are preliminary or of specialized interest, e.g., quick release reports, working papers, and bibliographies that contain minimal annotation. Does not contain extensive analysis.

- CONTRACTOR REPORT. Scientific and technical findings by NASA-sponsored contractors and grantees.
- CONFERENCE PUBLICATION.

Collected papers from scientific and technical conferences, symposia, seminars, or other meetings sponsored or cosponsored by NASA.

- SPECIAL PUBLICATION. Scientific, technical, or historical information from NASA programs, projects, and mission, often concerned with subjects having substantial public interest.

- TECHNICAL TRANSLATION. Englishlanguage translations of foreign scientific and technical material pertinent to NASA's mission.

Specialized services that complement the STI Program Office's diverse offerings include creating custom thesauri, building customized databases, organizing and publishing research results ... even providing videos.

For more information about the NASA STI Program Office, see the following:

- Access the NASA STI Program Home Page at http://www.sti.nasa.gov

- E-mail your question via the Internet to help@sti.nasa.gov

- Fax your question to the NASA Access Help Desk at (301) 621-0134

- Telephone the NASA Access Help Desk at (301) 621-0390

- Write to:

NASA Access Help Desk

NASA Center for AeroSpace Information 7121 Standard Drive

Hanover, MD 21076-1320 


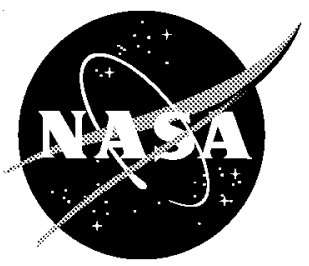

\section{A Base Drag Reduction Experiment on the X-33 Linear Aerospike SR-71 Experiment (LASRE) Flight Program}

Stephen A. Whitmore and Timothy R. Moes

Dryden Flight Research Center

Edwards, California

National Aeronautics and

Space Administration

Dryden Flight Research Center

Edwards, California 93523-0273 


\section{Acknowledgments}

The authors thank the SR-71 crew for allowing access to the aircraft during a high-pressure time near the end of the program. The authors also acknowledge the expert assistance of Dale Hilliard and Jerry S. Reedy of Kaye and Associates in applying the gritted paint to the flight experiment.

\section{NOTICE}

Use of trade names or names of manufacturers in this document does not constitute an official endorsement of such products or manufacturers, either expressed or implied, by the National Aeronautics and Space Administration.

Available from the following:

NASA Center for AeroSpace Information (CASI)

7121 Standard Drive

Hanover, MD 21076-1320

(301) 621-0390
National Technical Information Service (NTIS) 5285 Port Royal Road Springfield, VA 22161-2171 (703) $487-4650$ 


\title{
A BASE DRAG REDUCTION EXPERIMENT ON THE X-33 LINEAR AEROSPIKE SR-71 EXPERIMENT (LASRE) FLIGHT PROGRAM
}

\author{
Stephen A. Whitmore, ${ }^{*}$ Timothy R. Moes ${ }^{\dagger}$ \\ NASA Dryden Flight Research Center \\ Edwards, California
}

$\underline{\text { Abstract }}$

Drag reduction tests were conducted on the LASRE/ $\mathrm{X}$-33 flight experiment. The LASRE experiment is a flight test of a roughly 20-percent scale model of an $\mathrm{X}-33$ forebody with a single aerospike engine at the rear. The experiment apparatus is mounted on top of an SR-71 aircraft. This paper suggests a method for reducing base drag by adding surface roughness along the forebody. Calculations show a potential for base drag reductions of 8 to 14 percent. Flight results corroborate the base drag reduction, with actual reductions of 15 percent in the high-subsonic flight regime. An unexpected result of this experiment is that drag benefits were shown to persist well into the supersonic flight regime. Flight results show no overall net drag reduction. Applied surface roughness causes forebody pressures to rise and offset base drag reductions. Apparently the grit displaced streamlines outward, causing forebody compression. Results of the LASRE drag experiments are inconclusive and more work is needed. Clearly, however, the forebody grit application works as a viable drag reduction tool.

\section{$\underline{\text { Nomenclature }}$}

$$
\begin{array}{ll}
\begin{array}{l}
A_{\text {base }} \\
A_{\text {boat }}
\end{array} & \begin{array}{c}
\text { total base area for LASRE model, } \mathrm{ft}^{2} \\
\text { projected area of LASRE boat tail base } \\
\text { onto } \mathrm{y}-\mathrm{z} \text { plane, } \mathrm{ft}^{2}
\end{array} \\
\begin{array}{cc}
A_{\text {eng base }} & \begin{array}{c}
\text { projected area of engine plug base onto } \\
\mathrm{y}-\mathrm{z} \text { plane, } \mathrm{ft}^{2}
\end{array} \\
A_{\text {fence }} & \begin{array}{c}
\text { projected area of engine fence onto } \mathrm{y}-\mathrm{z} \\
\text { plane, } \mathrm{ft}^{2}
\end{array}
\end{array}
\end{array}
$$

\footnotetext{
*Vehicle Aerodynamics Group Leader, Senior Member, AIAA.
}

'Aerospace Engineer, Member, AIAA.

Copyright $(1999$ by the American Institute of Aeronautics and Astronautics, Inc. No copyright is asserted in the United States under Title 17, U.S. Code. The U.S. Government has a royalty-free license to exercise all rights under the copyright claimed herein for Governmental purposes. All other rights are reserved by the copyright owner.
$A_{\text {gap }}$

$A_{\text {grit }}$

$\boldsymbol{A}_{\text {meas }}$

Aramp

$A_{\text {wet }}$

$B_{\text {ref }}$

$C_{D_{\text {base }}}$

$\tilde{C}_{D_{\text {base }}}\left[M_{\infty}\right]$

$\tilde{C}_{D_{\text {base }}{ }^{(o)}}$

predicted base drag coefficient, incompressible flow conditions, referenced to base area

$C_{D_{\text {fore }}}$

forebody pressure drag coefficient, referenced to base area

$C_{D_{\text {fore }}}^{(1 \cdot i s c)}$

total viscous forebody drag coefficient, referenced to base area

$C_{D_{p}}$

total pressure drag coefficient for the

LASRE model, referenced to base area

$C_{D_{\text {para }} \text { base }}$

LASRE parasite drag coefficient, referenced to base area

$C_{D_{0}}$

zero-lift drag coefficient of the LASRE model, from balance, referenced to base area

$\tilde{C}_{D_{0}} \quad$ predicted zero-lift drag coefficient of the LASRE model, referenced to base area

$C_{D_{0}}^{(p)} \quad$ zero-lift drag coefficient of the LASRE model, from pressures, referenced to base area 


\begin{tabular}{|c|c|c|c|}
\hline$c_{f_{\text {base }}}$ & $\begin{array}{l}\text { forebody skin friction drag coefficient, } \\
\text { referenced to base area }\end{array}$ & psid & differential pressure, $1 \mathrm{~b} / \mathrm{in}^{2}$ \\
\hline$c_{f}^{(r o u g h)}$ & skin friction coefficient for rough flat & $p_{\infty}$ & freestream static pressure, $\mathrm{lb} / \mathrm{ft}^{2}$ \\
\hline & plate, referenced to $A_{\text {wet }}$ & $q_{i}$ & $\begin{array}{l}\text { weighting function for surface pressure } \\
\text { measurement }\end{array}$ \\
\hline$c_{f_{L}}^{(s m)}$ & $\begin{array}{l}\text { skin friction coefficient for smooth flat } \\
\text { plate, referenced to } A_{\text {wet }}\end{array}$ & $R e_{L}$ & Reynold's number based on length \\
\hline$\frac{C_{p}}{C}$ & pressure coefficient & $R_{\text {model }}$ & $\begin{array}{l}\text { offset from SR-71 instrument package to } \\
\text { model center of gravity, } \mathrm{ft}\end{array}$ \\
\hline$C_{p}$ & integrated surface pressure coefficient & & \\
\hline${\overline{C_{p_{\text {base }}}}}$ & integrated engine base pressure & sps & samples-per-second \\
\hline & coefficient & $S_{\text {ref }}$ & planform reference area \\
\hline $\begin{array}{l}\bar{C}_{p_{\text {boat }}} \\
\bar{C}\end{array}$ & $\begin{array}{l}\text { integrated boat tail pressure coefficient } \\
\text { integrated lower engine fence pressure }\end{array}$ & $V_{\text {base }}$ & $\begin{array}{l}\text { reflection exit velocity, at base of model, } \\
\mathrm{ft} / \mathrm{sec}\end{array}$ \\
\hline$p_{\text {fence }}$ & $\begin{array}{l}\text { coefficient } \\
\text {. }\end{array}$ & $V_{\infty}$ & freestream velocity, $\mathrm{ft} / \mathrm{sec}$ \\
\hline $\bar{C}_{p_{\text {fore }}}$ & integrated forebody pressure coefficient & $\mathrm{x}$ & longitudinal coordinate, $\mathrm{ft}$, in. \\
\hline$C_{p_{i}}$ & $\begin{array}{l}\text { pressure coefficient measured at i'th } \\
\text { pressure port }\end{array}$ & $\mathrm{y}$ & lateral coordinate, $\mathrm{ft}$ \\
\hline $\bar{C}_{p_{l e f t}}$ & $\begin{array}{l}\text { integrated left-nozzle ramp pressure } \\
\text { coefficient }\end{array}$ & $\mathrm{Z}$ & vertical coordinate, $\mathrm{ft}$ \\
\hline $\bar{C}_{p_{\text {right }}}$ & $\begin{array}{l}\text { integrated right-nozzle ramp pressure } \\
\text { coefficient }\end{array}$ & $\Delta C_{D_{\text {fore }}}^{(\text {i isc })}$ & $\begin{array}{l}\text { increment in total viscous forebody drag } \\
\text { coefficient caused by added forebody } \\
\text { roughness, referenced to base area }\end{array}$ \\
\hline$F_{\text {aero }}$ & $\begin{array}{l}\text { true force vector acting on LASRE } \\
\text { model, lbf }\end{array}$ & $\Delta C_{D_{\text {base }}}$ & $\begin{array}{l}\text { base drag reduction caused by added } \\
\text { forebody roughness, referenced to base } \\
\text { area }\end{array}$ \\
\hline$F_{f_{\text {Ram }}}$ & $\begin{array}{l}\text { friction force acting between reflection } \\
\text { plane and model, lbf }\end{array}$ & $\kappa_{s}$ & $\begin{array}{l}\text { equivalent sand-grain roughness of } \\
\text { surface extrusions, in. }\end{array}$ \\
\hline$F_{\text {raw }}$ & $\begin{array}{l}\text { raw force vector measured by LASRE } \\
\text { model balance, lbf }\end{array}$ & $v_{i}$ & weighting function scale factor \\
\hline$L$ & length, ft & $\rho_{\text {base }}$ & $\begin{array}{l}\text { local flow density, at reflection plane exit } \\
\text { at base of model, slug } / \mathrm{ft}^{3}\end{array}$ \\
\hline$m_{\text {model }}$ & $\begin{array}{l}\text { mass of the LASRE model, excluding } \\
\text { reflection plane, slugs }\end{array}$ & $\begin{array}{l}\rho_{\infty} \\
\omega\end{array}$ & $\begin{array}{l}\text { freestream flow density, slug/ } \mathrm{ft}^{3} \\
\text { vehicle angular velocity vector, } \mathrm{rad} / \mathrm{sec}\end{array}$ \\
\hline$M_{d i v}$ & $\begin{array}{l}\text { divergence drag rise Mach number } \\
\text { freestream Mach number }\end{array}$ & $\dot{\omega}$ & $\begin{array}{l}\text { vehicle angular acceleration vector, } \\
\mathrm{rad} / \mathrm{sec}^{2}\end{array}$ \\
\hline$N$ & number of ports used in integration & $\left(\frac{\partial \mathrm{x}}{\partial \mathrm{y}}\right)_{i}$ & $\begin{array}{l}\text { slope of model surface along } x-y \\
\text { direction at } i \text { 'th port }\end{array}$ \\
\hline $\begin{array}{l}\text { pbase } \\
\text { psia }\end{array}$ & $\begin{array}{l}\text { base pressure, } \mathrm{lb} / \mathrm{ft}^{2} \\
\text { absolute pressure, } \mathrm{lb} / \mathrm{in}^{2}\end{array}$ & $\left(\frac{\partial \mathrm{x}}{\partial \mathrm{z}}\right)_{i}$ & $\begin{array}{l}\text { slope of model surface along } \mathrm{x}-\mathrm{z} \\
\text { direction at } \mathrm{i} \text { 'th port }\end{array}$ \\
\hline
\end{tabular}




\section{$\underline{\text { Introduction }}$}

Current proposed shapes for reusable single-stage-toorbit vehicles like the Lockheed Martin X-33 and VentureStar ${ }^{\mathrm{TM}}$ reusable launch vehicle have extremely large base areas when compared to previous hypersonic vehicle designs. ${ }^{1}$ The comparatively large base areas for the X-33 and VentureStar ${ }^{\mathrm{TM}}$ are a consequence of the lifting-body shape of the vehicle, and the need to fit the rectangular linear aerospike engines into the base region. As a result, base drag-especially in the transonic flight regime-is expected to be quite large. Alternatively, the need for a low-drag profile for the ascent phase of the flight has resulted in a relatively clean, low-camber forebody shape for the X-33. Consequently, at low angles of attack one would expect the forebody drag of the X-33 to be relatively low; and that base drag would dominate the vehicle drag characteristics.

The unique configuration of the X-33, with its large base area and relatively low forebody drag, offers the potential for a high payoff in base drag reduction. This paper presents results of a base drag-reduction test, conducted on the X-33 Linear Aerospike SR-71 Experiment (LASRE). ${ }^{2}$ This flight experiment attempted to reduce base drag by increasing forebody surface roughness. This report presents results of the experiment, and compares the resulting low angle-ofattack drag numbers to the $\mathrm{X}-33$ wind tunnel data base. Effects of the aerospike rocket firing on the base drag characteristics are not addressed.

Use of trade names or names of manufacturers in this document does not constitute an official endorsement of such products or manufacturers, either expressed or implied, by the National Aeronautics and Space Administration.

\section{Background on the LASRE Flight Experiment}

The LASRE experiment is a flight test of a roughly 20-percent half-span scale model of an X-33 forebody with a single aerospike rocket engine at the rear. As shown in figure 1, the entire test model is mounted on top of an SR-71 aircraft. It was intended that LASRE flight test data would be used to define the aerospike engine performance under realistic flight conditions and to determine plume interactions with the base and engine cowl areas. NASA Dryden recently concluded

\footnotetext{
${ }^{\mathrm{TM}}$ VentureStar is a registered trademark of Lockheed Martin, Inc., Mountain View, California.
}

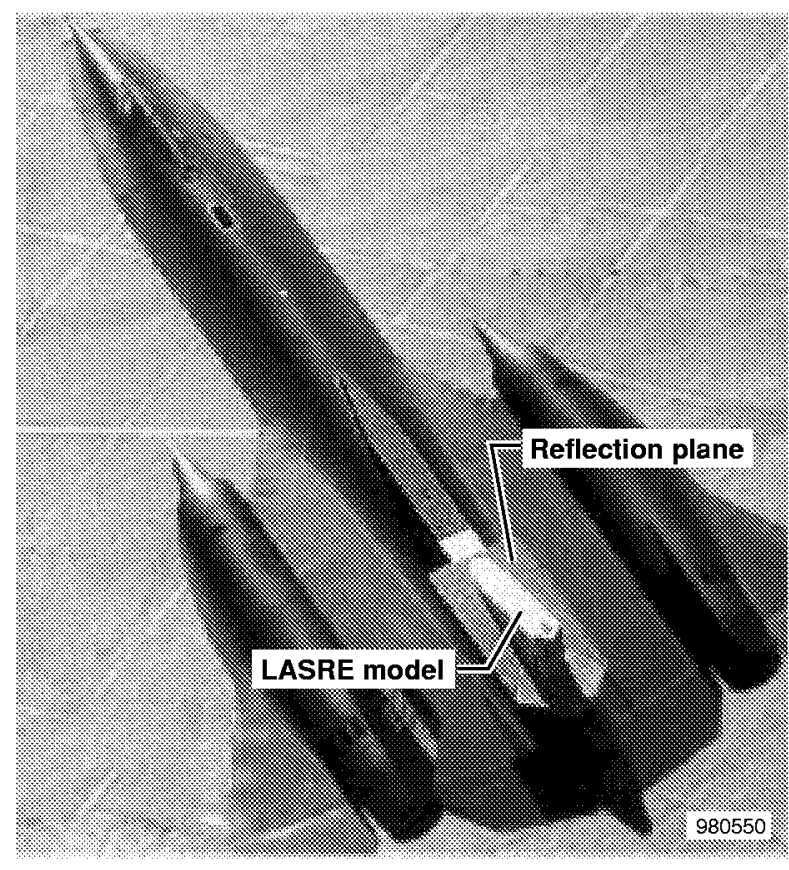

Figure 1. The LASRE pod mounted on top of the SR-71 aircraft.

testing of the LASRE without having actually fired the rocket engine in flight.

The model is mounted onto the aircraft so that the lateral axis is aligned parallel to the normal axis of the SR-71. This alignment causes the angle of sideslip for the SR-71 aircraft to be equivalent to angle of attack for the LASRE model. Thus, with a zero-angle-of-sideslip flight condition for the SR-71 aircraft, the model is essentially flying at zero angle of attack. To achieve better flow quality, a reflection plane was mounted between the SR-71 and the model. The reflection plane shields the model from the SR-71 flow field.

Model mold lines are constructed from a 30-in. diameter cylinder which is swept away from the longitudinal axis by an angle of $20^{\circ}$. At the nosetip, the cylinder is faired smoothly with a 15-in. radius hemisphere. Figure 2 shows a three-view line drawing of the model and documents the primary geometrical components - the forebody, boat tail, nozzle ramps, base plug, and engine fences. Figure 3 compares outer mold-lines of the LASRE to a 20-percent scale top-view of the X-33. Comparisons show a fairly close match. Table 1 compares some vital geometric properties of the LASRE model to those of the X-33. 

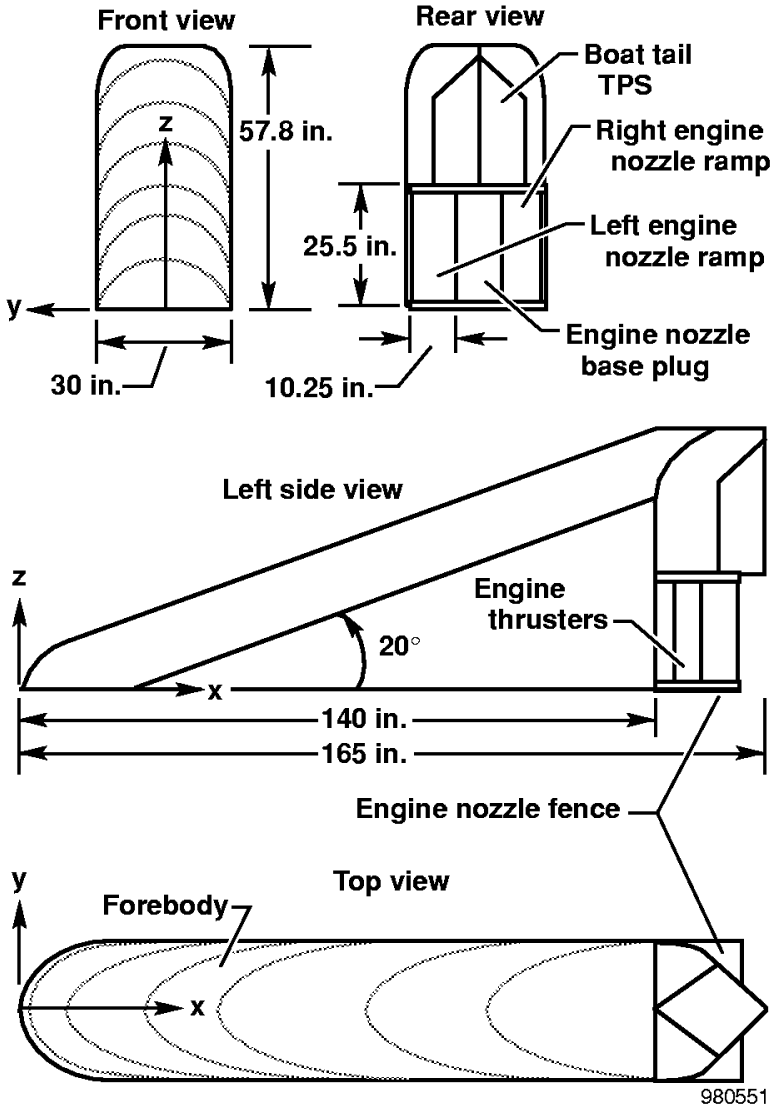

Figure 2. The LASRE test model.

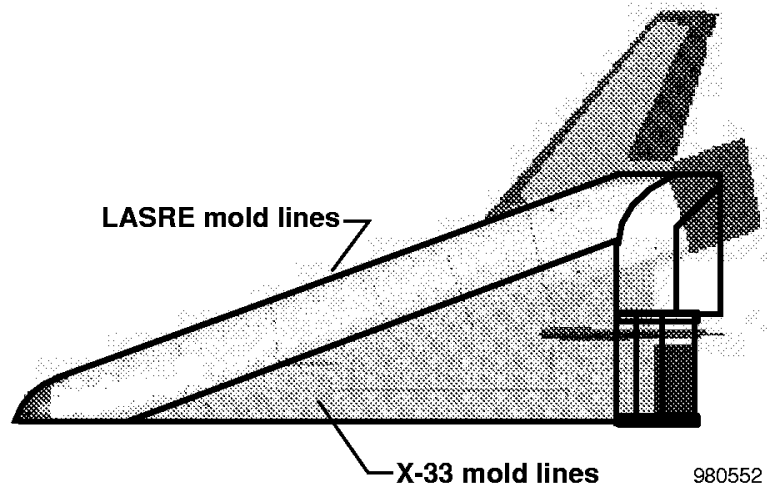

Figure 3. A comparison of the LASRE outer mold lines with the $\mathrm{X}-33$.
Table 1. Comparison of the LASRE and X-33 reference dimensions. $^{2}$

\begin{tabular}{cccc}
\hline \hline Symbol & \multicolumn{1}{c}{ Description } & $\mathrm{X}-33$ & LASRE \\
\hline$S_{\text {ref }}$ & $\begin{array}{c}\text { Planform reference } \\
\text { area }\end{array}$ & $1608 \mathrm{ft}^{2}$ & $32.15 \mathrm{ft}^{2}$ \\
& $\begin{array}{l}\text { Reference length } \\
L_{\text {ref }}\end{array}$ & $63.2 \mathrm{ft}$ & $13.12 \mathrm{ft}$ \\
$B_{\text {ref }}$ & $\begin{array}{l}\text { Reference span } \\
\left.\text { (60 percent of } L_{r e f}\right)\end{array}$ & $36.6 \mathrm{ft}$ & $3.75 \mathrm{ft}$ \\
$A_{\text {wet }}$ & $\begin{array}{l}\text { Wetted area } \\
\text { (excluding base) }\end{array}$ & $5120 \mathrm{ft}^{2}$ & $101.62 \mathrm{ft}^{2}$ \\
$A_{\text {base }}$ & Base area & $466.9 \mathrm{ft}^{2}$ & $12.04 \mathrm{ft}^{2}$ \\
\hline \hline
\end{tabular}

Note: LASRE reference data are for a half-span vehicle.

\section{Instrumentation and Processing of the Onboard Measurements}

In order to measure performance of the Linear Aerospike engine under a variety of flight conditions, the model was mounted to the SR-71 with a pylon that was instrumented with 8 load cells oriented to allow a six-degree-of-freedom measurement of the total forces and moments. The model was also instrumented with surface pressure ports on the forebody, boat tail, base, engine ramps, and the lower engine fence.

Other onboard instrumentation included the airdata measurements-Mach number, airspeed, angle of attack, angle of sideslip, and altitude-from the onboard airdata system of the SR-71, and vehicle accelerations and angular rates from strapdown sensors located near the vehicle center of gravity. All onboard analog instrumentation were sampled using 12-bit pulse code modulation (PCM) and telemetered to the ground for postflight analysis. The airdata parameters were telemetered and recorded at 50 samples-per-second (sps). Onboard accelerometer and rate-gyroscope readings were telemetered and recorded at $200 \mathrm{sps}$.

\section{Force Balance Data Measurements}

The force balance measurements consisted of 8 load cells, oriented to give outputs proportional to the forces acting along the axial, vertical, and lateral directions on the balance (fig. 4). A calibration tensor measured by Lockheed Martin (Palmdale, California) prior to delivering the LASRE experiment to NASA Dryden 


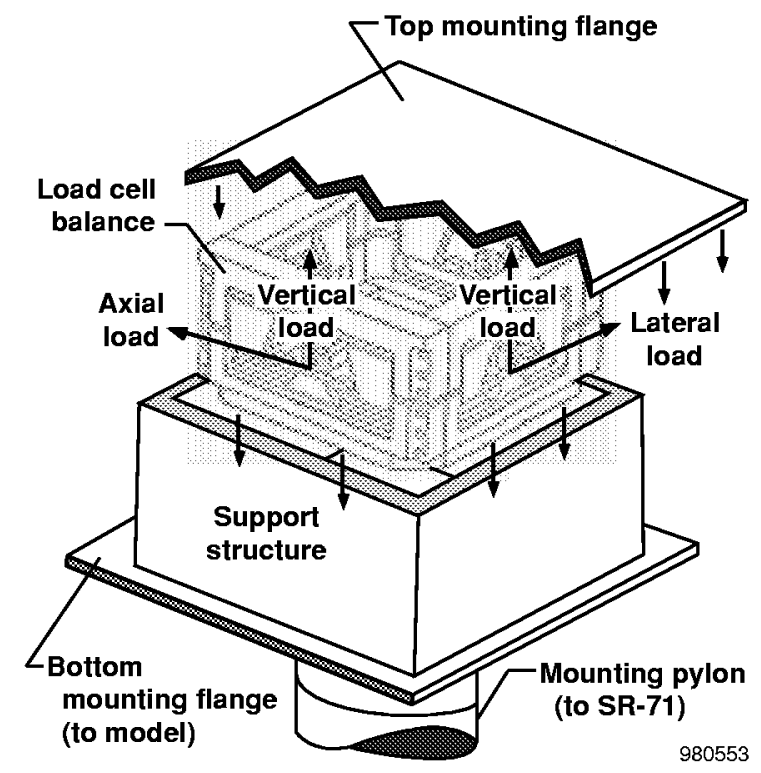

Figure 4. Schematic of the LASRE force balance.

was used to relate the output readings to the true forces and moments acting on the balance. The balance was not re-calibrated during the course of this flight program.

Raw force-balance data were sampled at $50 \mathrm{sps}$, and these were low-pass filtered using a second-order Butterworth digital filter ${ }^{3}$ to remove noise caused by structural vibrations and aerodynamic turbulence. Filter latency was accounted for by time-skewing the data after filtering. The filtered data were corrected for zerooffsets using preflight and postflight zero-tare data. The zero-readings were taken for each load cell by averaging one minute of data each, from both preflight and postflight. The calibration tensor was then used to compute the axial, normal, and side loads, and pitch, roll, and yaw moments acting at the balance.

To determine the true aerodynamic forces acting on the model, it is necessary to remove the centrifugal force and vehicle accelerations acting at the model center of gravity. These corrections were computed using the strapdown instruments onboard the SR-71 aircraft. The vector equations for the force transformations are

$$
\begin{aligned}
F_{\text {aero }} & =F_{\text {raw }}-\left\{m_{\text {model }} .\right. \\
& {\left.\left[A_{\text {meas }}+\left[\omega \times \omega \times R_{\text {model }}+\omega \times R_{\text {model }}\right]\right]\right\} }
\end{aligned}
$$

In equation $1, m_{\text {model }}$ is the mass of the model, (the part of the total experiment mounted above the reflection plane), $F_{\text {aero }}$ is the vector of corrected aerodynamic loads acting on the model, $F_{\text {raw }}$ is the force vector calculated from the uncorrected load data, $\boldsymbol{A}_{\text {meas }}$ is the measured linear acceleration vector, $\omega$ is the angular rate of the vehicle, $\dot{\omega}$ is the angular acceleration of the vehicle, and $R_{\text {model }}$ is the vector distance from the location of the SR-71 aircraft accelerometer package to the center of gravity of the model. The center of gravity of the LASRE model lies $39.025 \mathrm{ft}$ aft, $7.408 \mathrm{ft}$ above, and $2.708 \mathrm{ft}$ inboard of the SR-71 accelerometer package. For the SR-71 LASRE experiment, angular acceleration was not directly measured; instead angular acceleration was computed by numerically differentiating the angular rate vector. ${ }^{4}$

\section{$\underline{\text { Surface Pressure Measurements }}$}

Pressure instrumentation consisted of flush pressure taps distributed on the forebody, boat tail, engine ramps, engine base plug, thruster cowling, and engine fences. A total of 95 ports were distributed on the forebody and boat tail. Locations of the forebody and boat tail ports are shown in figure 5 . In addition 58 ports were located in the engine base area, with 20 pressure ports located on the left engine ramp, 22 ports on the right engine ramp, and 16 ports on the engine base plug. An additional 2 pressure ports were located on the trailing edge of the lower engine fence. Figure 6 shows the locations of the engine pressure ports.

Forebody, boat-tail, and nozzle surface pressures were sensed using electronically scanned pressure (ESP) modules. Because of pressure ranges expected during aerospike engine hot-fire tests, engine ramp and fence pressures were sensed using \pm 50 psid pressure sensors; all other surface pressure measurements were made using \pm 10 ESPs. All ESPs were referenced to a highly accurate $0-38$ psia 20-bit digital pressure transducer. The reference pressure was added to the differential ESP readings to determine the absolute local pressure reading. Temperature environments of the ESP were controlled using heater blankets. Zero-shift corrections using preflight and postflight tare readings were also performed. To reduce the effects of structural vibrations and aerodynamic turbulence, pressure measurements were digitally filtered. All pressure data were measured at $50 \mathrm{sps}$.

\section{Flight Test Maneuvers}

Acceleration data from subsonic to supersonic flight conditions were used in this analysis. Initially, level altitude accelerations were flown for envelope 

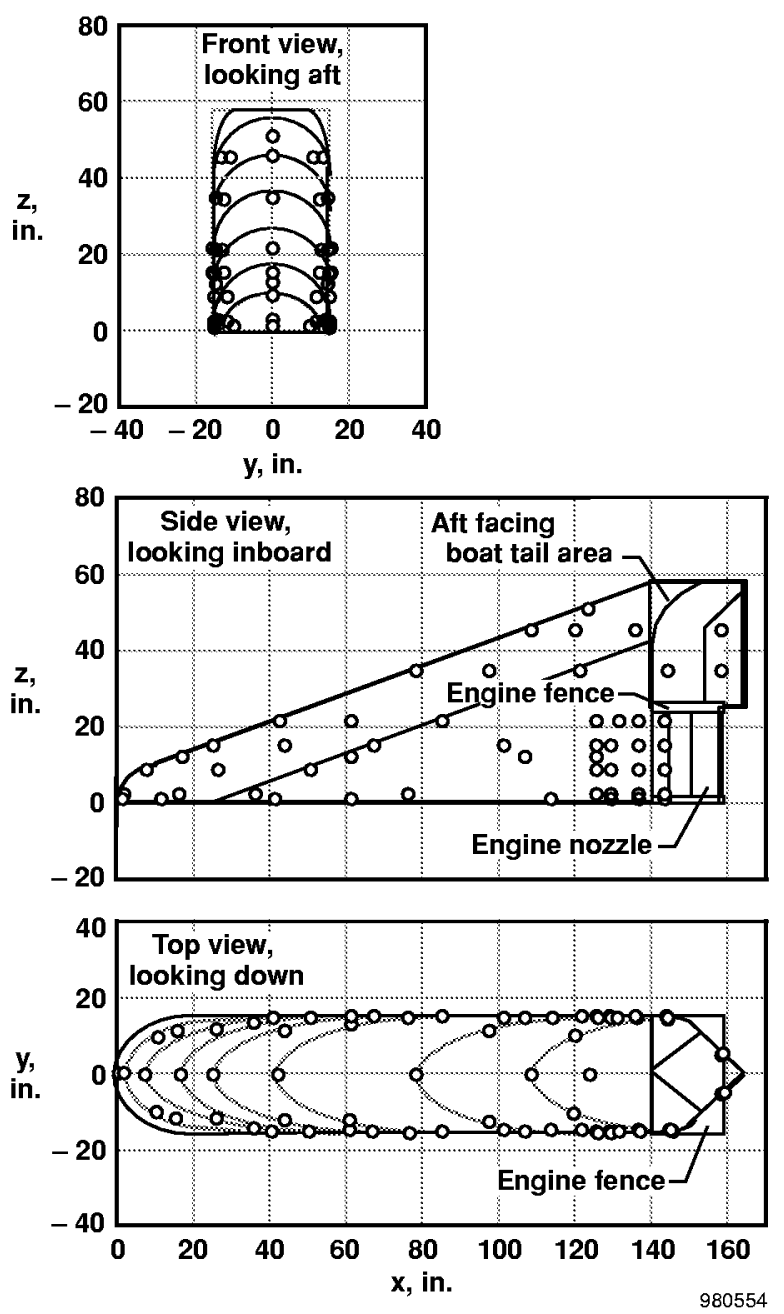

Figure 5. Port locations on LASRE forebody and boat tail.

expansion and flutter clearance. Once the flight envelope clearance was obtained, a more fuel-efficient dipsy maneuver was used to accelerate through the large transonic drag rise. The dipsy maneuver began at $28,000 \mathrm{ft}$ and Mach 0.9. The pilot put the aircraft into a slight dive to help get through the transonic drag rise and then leveled the aircraft at approximately Mach 1.07 and an altitude of $25,000 \mathrm{ft}$, which was the minimum altitude cleared for transonic flight. The aircraft continued to accelerate at an altitude of $25,000 \mathrm{ft}$ until it obtained an equivalent airspeed of $450 \mathrm{kn}$, at which point the pilot initiated a constant equivalent airspeed climb to the desired Mach number. Structural load restrictions on the LASRE experiment required that the angle of sideslip - equivalent to angle of attack in the model axis-be restricted to less than two degrees. Because of this restriction, all of the drag data obtained are essentially for the zero-lift flight condition $-C_{D_{0}}$.

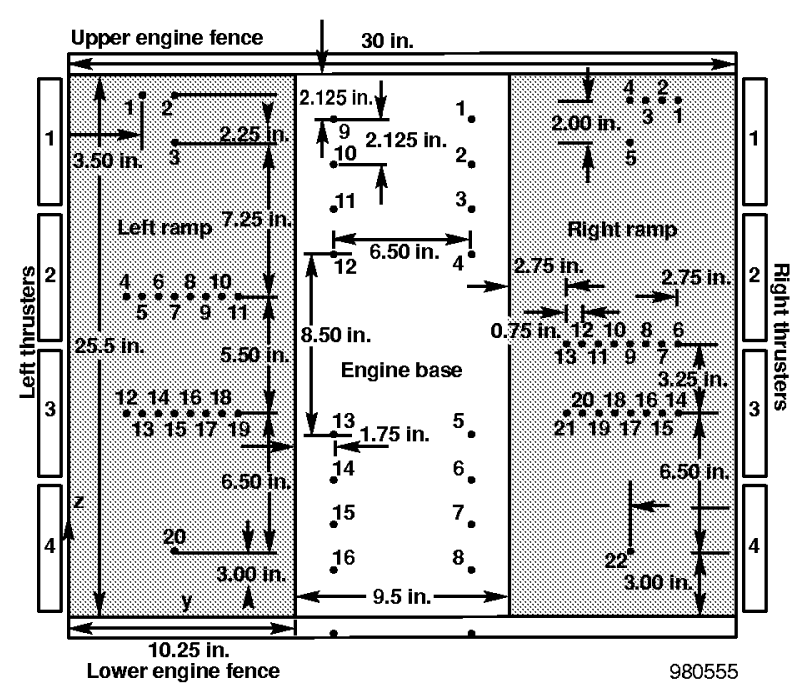

Figure 6. Layout of LASRE engine nozzle plug and ramp pressure port.

\section{Baseline Drag Measurements on the LASRE Model Configuration}

Baseline drag measurements on the clean LASRE configuration will be presented first. The clean configuration is defined as the model without added forebody surface roughness. Data derived from four typical flight maneuvers performed during flights 46 , 47,48 , and 49 are used to illustrate the drag properties of the model. These baseline drag data verify the resolution, repeatability, and accuracy of the measurements; and substantiate the earlier assertions that base drag is the dominating drag-force component. In the remainder of this paper, all drag coefficient data will be referenced to the base area of the LASRE model as presented in table 1 .

\section{Overall Model Drag Measurements}

Figure 7 shows the overall drag coefficient, $C_{D_{0}}$, for the clean LASRE model plotted as a function of Mach number. Repeatability of the data are excellent, having a total scatter band of less than 0.015. For comparison purposes wind-tunnel derived values for the $\mathrm{X}-33$ total $C_{D_{0}}$ are also plotted. The very large transonic drag rise observed on the flight data does not show up on the wind tunnel predictions. Reasons for the transonic drag difference are not definite at this point; however, it is possible that this difference is an effect of the stingmount used to support the X-33 wind tunnel model. 


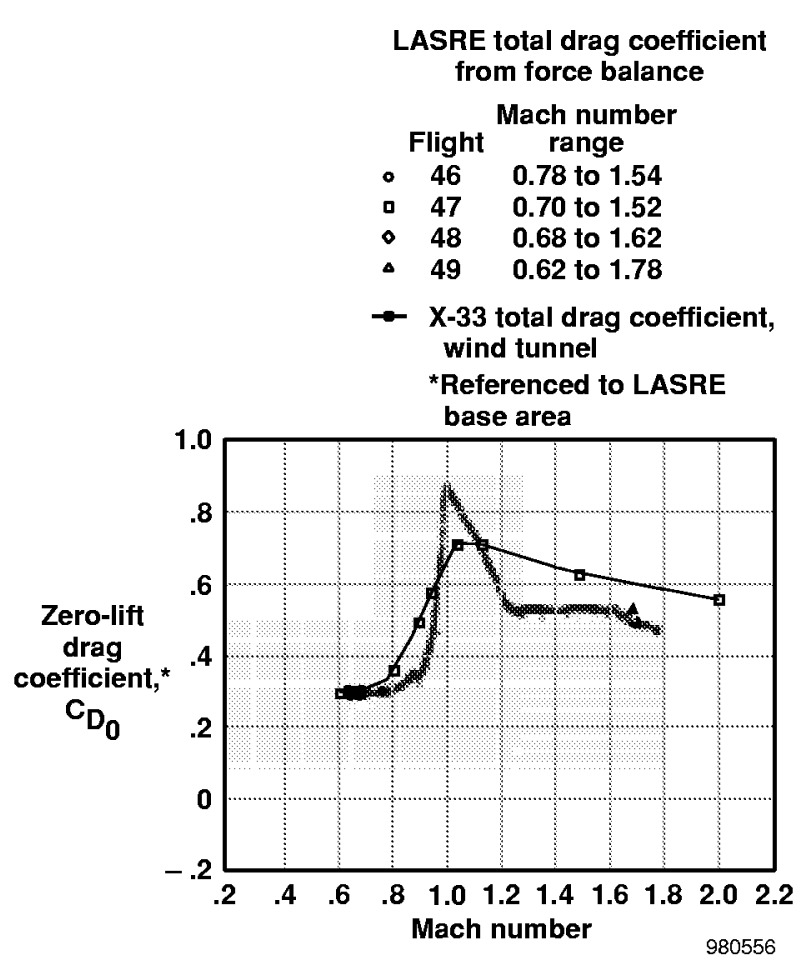

Figure 7. Baseline LASRE total zero-lift drag coefficient.

Individual Components of the Overall Model Drag Coefficient

The shape of the LASRE $C_{D_{0}}$ curve as a function of Mach number can be better understood by examining the individual drag-force components acting on the model. Since the LASRE model has no camber and nominally flies at zero local angle of attack, induced drag-due-to-lift is considered to be negligible. Thus there are 3 remaining drag components which must be considered as important:

1. Base and boat tail drag,

2. Forebody pressure-profile drag, and

3. Viscous drag from forebody skin-friction and residual parasite drag.

Effects of each component on the total LASRE drag are now presented.

\section{$\underline{\text { Surface Pressure Integration }}$}

Forebody, boat tail, and nozzle base drag coefficients are computed by numerically integrating the pressure measurements along the surface of the body. The pressure port distribution on the LASRE model is not dense enough to allow a full three-dimensional geometric integration of the pressures. If a geometrical grid were used to numerically integrate the pressures, the uneven port spacing would give far too much area weighting to the ports located in the sparsely populated regions. Instead, for a given geometrical component (such as the forebody surface) the surface integral was mechanized as a weighted average of the measured pressures.

$$
\overline{C_{p}}=\frac{\sum_{i=1}^{N}\left[q_{i} C_{p_{i}}\right]}{\sum_{i=1}^{N}\left[q_{i}\right]}
$$

Instead of weighting pressures by their local area, the weighting function applied in equation 2 is the projection of the local surface onto the $y-z$ plane,

$$
q_{i}=\frac{v_{i}}{\sqrt{1+\left(\frac{\partial x}{\partial y}\right)_{i}^{2}+\left(\frac{\partial x}{\partial z}\right)_{i}^{2}}}
$$

Equation 3 weights more heavily ports that are aligned more perpendicular to the drag axis. The numerical integration was performed for 6 geometrical components on the model:

1. the model forebody, aft to $140 \mathrm{in}$. behind the nosetip,

2. the engine nozzle left ramp,

3. the engine nozzle right ramp,

4. the engine nozzle base plug,

5. the LASRE model boat tail, and

6. the lower engine fence.

In equation $3, v_{i}$ is an arbitrary weighting function scale factor which was assigned to give better run-to-run data consistency. For the base, ramp, boat tail, and fence integrations, the value of $v_{i}$ was always unity. For the forebody integration, ports along the model centerline, and on the flat side-fairings unity values for $v_{i}$ were assigned. Ports along the sides of the swept cylindrical forebody were assigned values of $v_{i}=1.5$. This weighting increment helped to account for the sparseness of ports along the swept cylindrical sides of the forebody. 
Once the individual pressure coefficients of each geometrical component are determined, surface pressure drag is calculated as the area-weighted average of integrated pressure coefficients for individual geometrical components,

$$
\begin{aligned}
& C_{D_{p}}=\bar{C}_{P_{\text {fore }}}- \\
& {\left[A_{\text {ramp }}\left\{\bar{C}_{p_{\text {left }}}+\bar{C}_{p_{\text {right }}}\right\}+A_{\text {eng base }} \bar{C}_{p_{\text {base }}}\right.} \\
& \left.+A_{\text {boat }} \bar{C}_{p_{\text {boat }}}+A_{\text {fence }}{\overline{C_{p}}}_{\text {fence }}\right] / \\
& {\left[2 A_{\text {ramp }}+A_{\text {eng base }}+A_{\text {boat }}+A_{\text {fence }}\right]}
\end{aligned}
$$

The resulting base drag coefficient, $C_{D_{\text {base }}}=\overline{-C_{p_{b a s e}}}$, and forebody pressure drag coefficient, $C_{D_{\text {fore }}}=\bar{C}_{p_{\text {fore }}}$, are presented as a function of Mach number in figure 8 . For comparison purposes a fairing of the total drag coefficient, derived from figure 7 , is also presented. In the subsonic flight regime base drag remains relatively

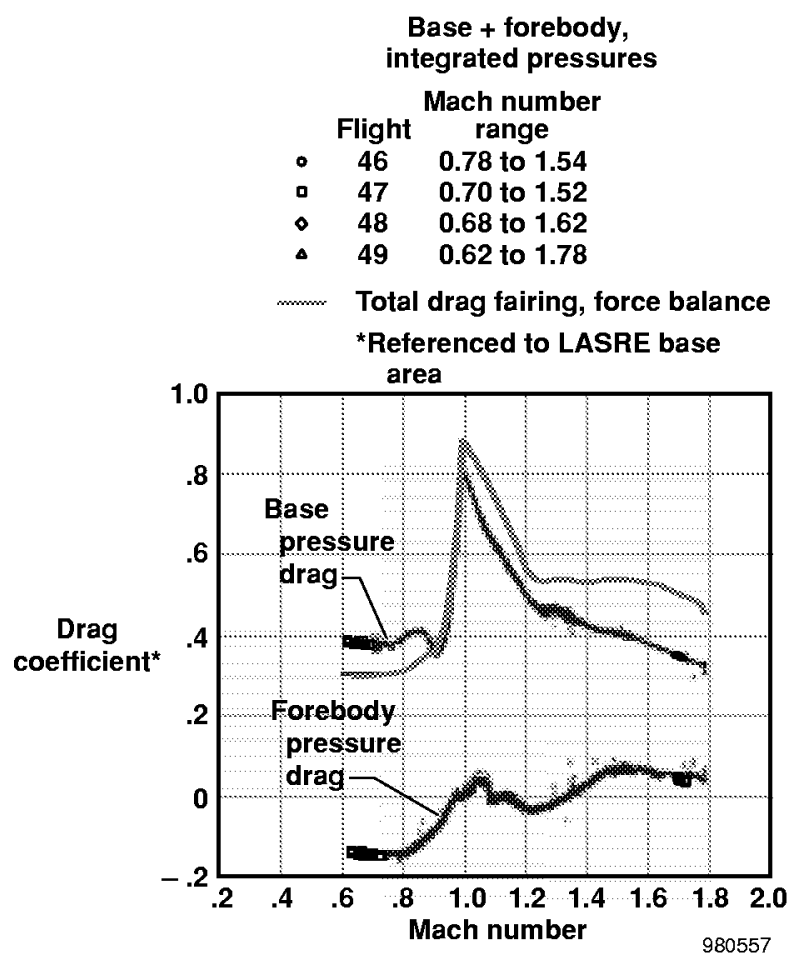

Figure 8. Comparison of the total LASRE drag coefficient with the base and forebody pressure drag coefficients. constant at approximately 0.38 until the divergence drag rise Mach number, $M_{d i}$, of approximately 0.90 is reached. After the divergence Mach number is reached, compressibility effects dominate and base drag coefficient rises rapidly. Beyond Mach 1, base drag drops off steadily. In the subsonic flight regime, base drag accounts for approximately 125 percent of the overall model drag. Approximately 80 percent of the transonic drag rise can be attributed to compressibility effects on base drag.

Since base drag is higher than overall model drag for subsonic flight conditions, one would expect a substantial amount of forebody suction to occur. The lower curve in figure 8 verifies this expectation. The forebody drag coefficient is negative until the transonic drag rise is encountered. Even in the transonic flight regime, forebody drag coefficient accounts for less than 8 percent of the total model drag coefficient. The strength of forebody suction is likely a result of a clean forebody shape for the LASRE. As mentioned previously, the mold lines for the LASRE forebody are a $20^{\circ}$ swept cylinder faired to flat sidepanels. This shape ensures that a significant adverse pressure gradient does not occur along the forebody.

This premise is illustrated in figure 9(a) where the forebody pressure distribution at Mach 0.70 is plotted as a function of the vertical (z) and longitudinal ( $\mathrm{x}$ ) coordinates. Figure 9 (b) shows locations of the pressure ports on the forebody. From the nosetip to approximately $40 \mathrm{in}$. aft, the pressure gradient is strongly favorable. Between 40 in. and 100 in. aft, the pressure gradient is almost flat; and beyond $100 \mathrm{in}$. aft, the pressure gradient becomes strongly favorable again. Although the surface pressure gradient between 40 in. and $100 \mathrm{in}$. aft is approximately neutral, the boundary layer in this region is clearly turbulent ${ }^{5}$ and flow separation is very unlikely. Pressure distributions for other Mach numbers have a similar profile.

\section{$\underline{\text { Skin Friction and Parasite Drag Coefficients }}$}

Total drag coefficient, $C_{D_{0}}$, is compared with overall pressure drag coefficient, $C_{D_{p}}$, in figure 10. Residuals between the two curves are also plotted. Obviously, residual data include measurement errors in both the force balance and surface pressure data; however, the residual data represent a crude measure of the combined viscous ${ }^{6}$ drag forces acting on the model. As will be shown in the next section, these viscous forebody forces 


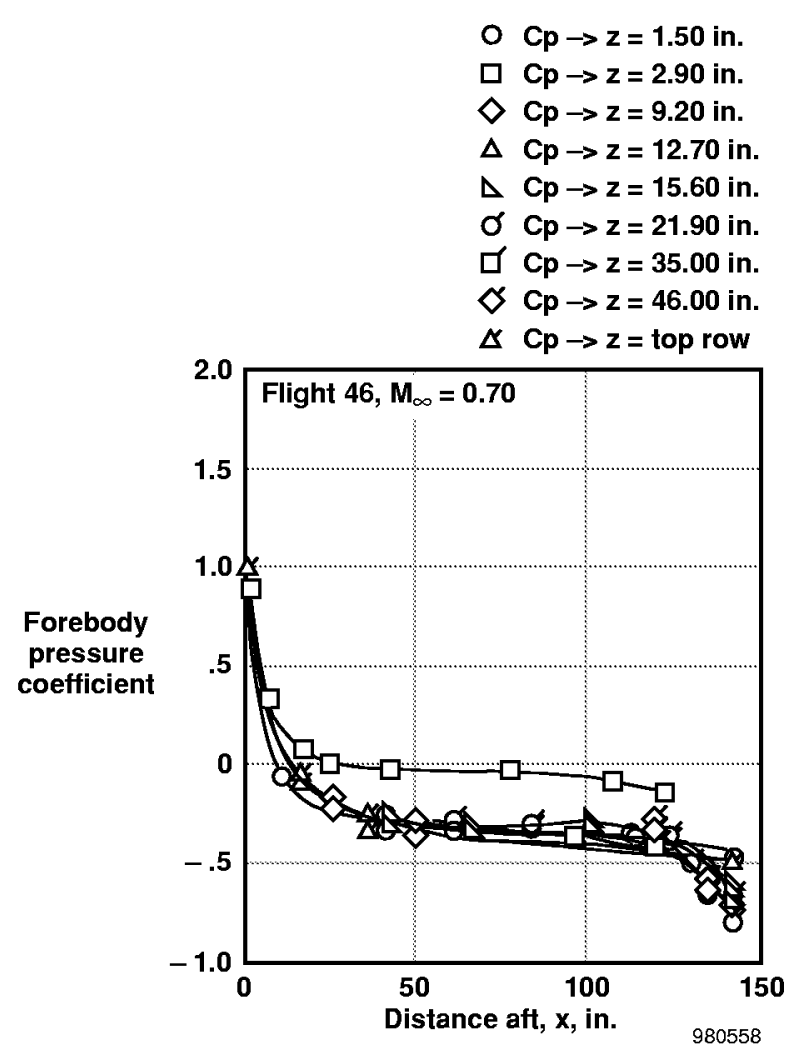

(a) Forebody pressure distribution.

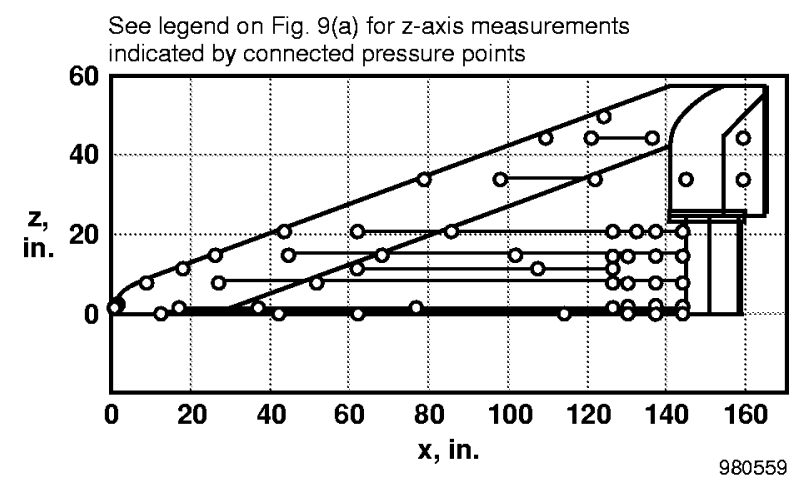

(b) Pressure ports on side view of forebody.

Figure 9. LASRE forebody pressure data, Flight 046, Mach 0.70 .

strongly influence the base drag. As a check on the accuracy of this crude viscous drag measurement, an estimate of the viscous forebody drag coefficient, $C_{D_{\text {fore }}}^{(v i s c)}$, is also calculated. For the LASRE model $C_{D_{\text {fore }}}^{(v i s c)}$ has two principal components: (1) the forebody skin friction drag and (2) the ram drag resulting from a 1-inch

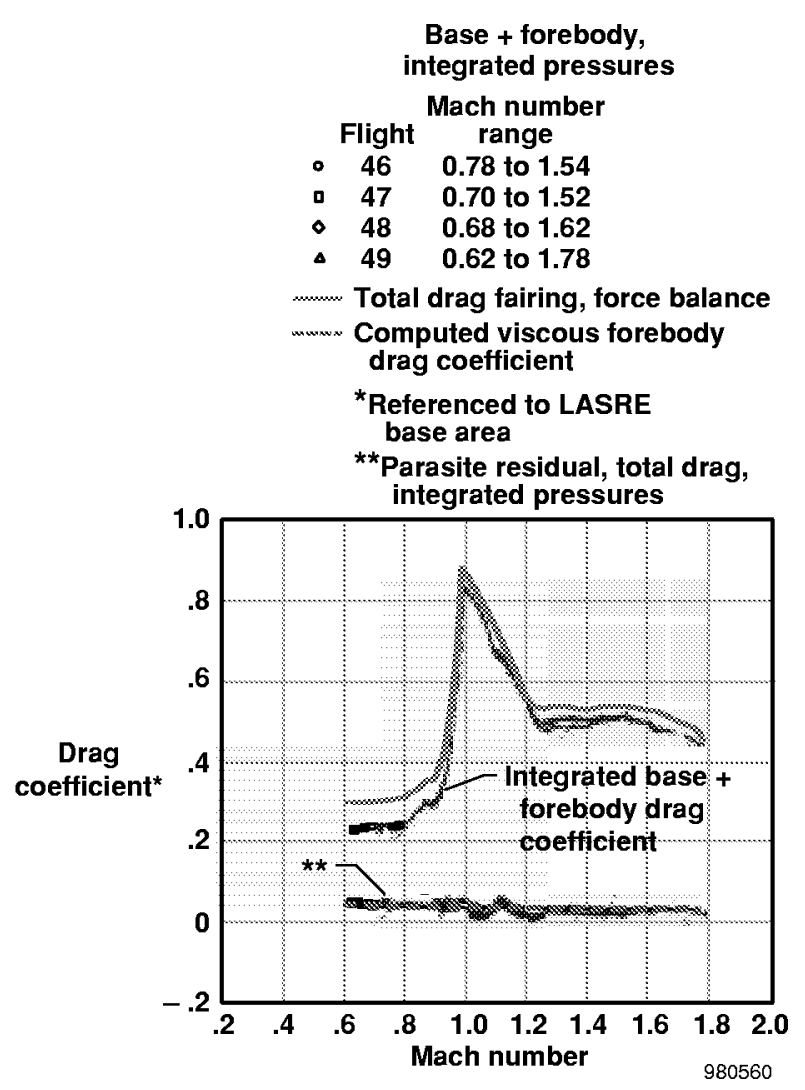

Figure 10. Comparison of the total LASRE drag coefficient with total pressure drag coefficient.

gap between the lower side of the model and the reflection plane. The ram drag is considered as equivalent to the parasite drag which forms on more complex aircraft configurations.

The forebody skin friction coefficient (referenced to the base area of the LASRE model) was evaluated by numerically solving the nonlinear equation for the Schoenherr line, ${ }^{7}$

$$
\begin{aligned}
& \frac{1}{\sqrt{{ }^{f_{f_{\text {base }}} \cdot\left[\frac{A_{\text {base }}}{A_{\text {wet }}}\right]}}}= \\
& 4.1322 \log \left[R e_{L} \cdot c_{f_{\text {base }}} \cdot\left[\frac{A_{\text {base }}}{A_{\text {wet }}}\right]\right]
\end{aligned}
$$

where, $R e_{L}$ is the forebody Reynold's number, $A_{\text {base }}$ is the base area, and $A_{w e t}$ is the wetted area of the forebody (table 1).

The parasite drag (referenced to the base area of the LASRE model) is calculated by performing a 
one-dimensional momentum and force balance in the axial direction

$$
\begin{aligned}
& A_{\text {gap }}\left(\rho_{\infty} V_{\infty}^{2}-\rho_{\text {base }} V_{\text {base }}^{2}\right)= \\
& 2 F_{f_{\text {Ram }}}-A_{\text {gap }}\left(p_{\infty}-p_{\text {base }}\right)
\end{aligned}
$$

In equation $6, A_{g a p}$ is the frontal projection area of the gap between the model and reflection plane, and $F_{f_{\text {Ram }}}$ is the skin friction force acting between the reflection plane and the lower surface of the model. Normalizing by freestream dynamic pressure and LASRE base area, equation 6 becomes

$$
\begin{aligned}
& \frac{\left(\rho_{\infty} V_{\infty}^{2}-\rho_{\text {base }} V_{\text {base }}^{2}\right)}{\frac{1}{2} \rho_{\infty} V_{\infty}^{2}}= \\
& \quad 2 \frac{F_{f_{\text {Ram }}}}{\frac{1}{2} \rho_{\infty} V_{\infty}^{2} A_{\text {base }}} \frac{A_{\text {base }}}{A_{\text {gap }}}-\frac{\left(p_{\infty}-p_{\text {base }}\right)}{\frac{1}{2} \rho_{\infty} V_{\infty}^{2}}
\end{aligned}
$$

Assuming that exit velocity is much smaller than entrance velocity, $\quad \rho_{\infty} V_{\infty}^{2}>\rho_{\text {base }} V_{\text {base }}^{2}, \quad$ and defining $C_{D_{\text {para }}} \equiv F_{f_{\text {Ram }}} /\left(A_{\text {base }} \rho_{\infty} V_{\infty}^{2} / 2\right)$ equation 7 reduces to

$$
C_{D_{\text {para } a s e}}=\frac{A_{\text {gap }}}{A_{\text {base }}}\left[1+\frac{1}{2} C_{D_{\text {base }}}\right]
$$

As mentioned earlier, total viscous forebody drag coefficient is the sum of the skin friction and parasite drag coefficients (referenced to base area)

$$
C_{D_{\text {fore }}}^{(v i s c)}=C_{f_{\text {base }}}+C_{D_{\text {para }} \text { base }}
$$

$C_{D_{\text {fore }}}^{(\text {i isc) }}$ is also plotted on figure 10. The computed values show reasonable agreement when compared to the residual data.

\section{Comparison of the Drag Coefficients Computed Using the Two Methods}

If calculated values for $C_{D_{\text {fore }}}^{(1 i s c)}$ are added to integrated pressure drag, $C_{D_{p}}$, an estimate of total model drag coefficient, $C_{D_{0}}^{(p)}$, is generated independently of the force balance measurements. The two independent drag coefficient estimates are compared in figure 11. Residuals between the two estimates, $C_{D_{0}}-C_{D_{0}}{ }^{(p)}$, are also plotted. The average difference between the two

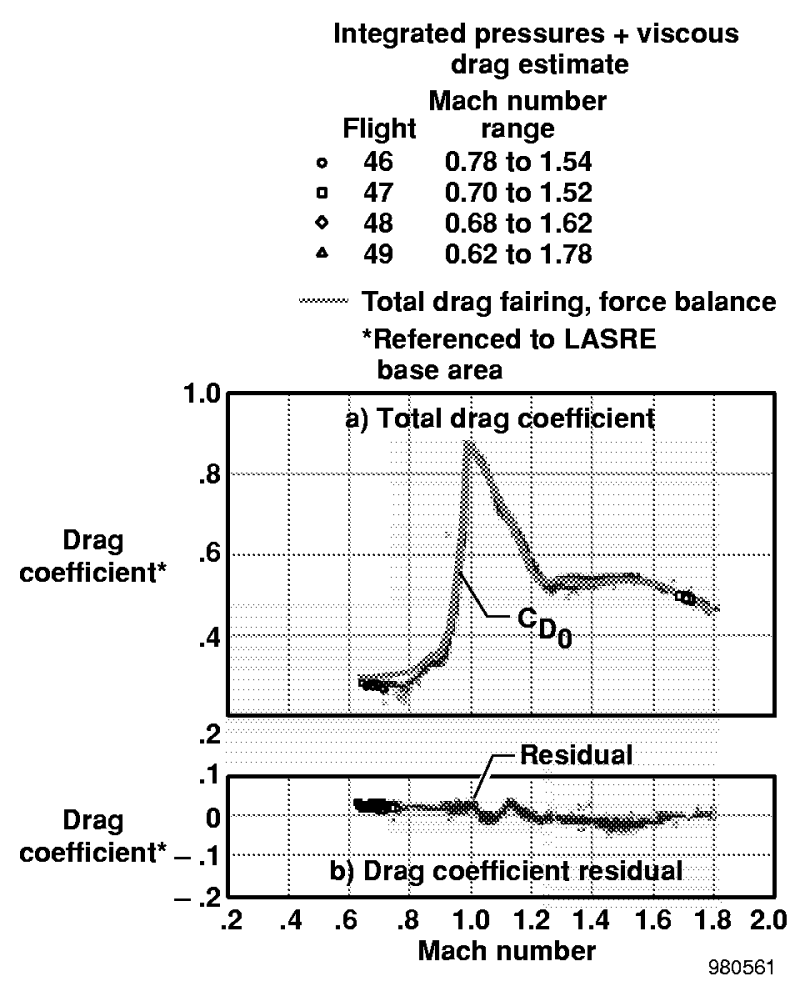

Figure 11. Comparison of total surface pressure coefficients.

estimates is approximately 0.015, and the maximum deviation is 0.04 . Because there are more uncertainties involved in deriving the estimate of $C_{D_{0}}^{(p)}$, it is likely that pressure-derived total drag coefficient estimates contribute a larger portion of the overall errorespecially in the transonic flight regime.

\section{Development of a Drag Reduction Strategy}

The data presented in figures 8 through 11 clearly support earlier assertions that base drag dominates the overall drag LASRE. For subsonic conditions Saltzman ${ }^{1}$ and Hoerner $^{7}$ have demonstrated a well-defined correlation between $C_{D_{\text {fore }}}^{(\text {visc) }}$ and $C_{D_{\text {base }}}$ for vehicles with a wide variety of shapes, sizes, and base-to-wetted area ratios. For two-dimensional shapes Hoerner ${ }^{7}$ has demonstrated that the subsonic correlation is approximated by the empirical formula

$$
C_{D_{\text {base }}}=\frac{.135}{\sqrt[3]{C_{D_{\text {fore }}}^{(\text {visc }}}}
$$


For three-dimensional shapes, the correlation formula is

$$
C_{D_{\text {base }}}=\frac{0.029}{\sqrt{C_{D_{\text {fore }}}^{(\text {(isc) }}}}
$$

Saltzman ${ }^{1}$ has found that for large-scale reentry-class flight vehicles the two-dimensional equation is a more accurate representation of the flight data. Based on this reasoning, equation 10 will be preferred in this analysis.

The reasons for the correlation predicted by equations 10 and 11 become more clear if one examines flow visualizations images of the LASRE obtained in the NASA Dryden Flow-Visualization Facility. ${ }^{8}$ Figure 12 shows water-tunnel flow images taken from tests of a 2.5-percent scale model of the LASRE/SR-71 configuration. Although the Reynolds numbers for the water tunnel tests $(\sim 1000)$ are significantly lower than for flight $\left(\sim 2-5 \times 10^{6}\right)$, nevertheless, the images presented serve as a good illustration of the LASRE base flow characteristics in the absence of engine thrust. The images clearly show the external freestream flow pumping fluid away from the engine base. This pumping effect reduces base pressures significantly. The forebody boundary layer arriving at the edge of the model acts as an insulating layer between the external flow and the separated base area. This insulating layer reduces the effectiveness of the pumping mechanism. Because the thickness of the forebody boundary layer is directly related to the viscous forebody forces, the source of the correlation of equation 10 becomes evident.

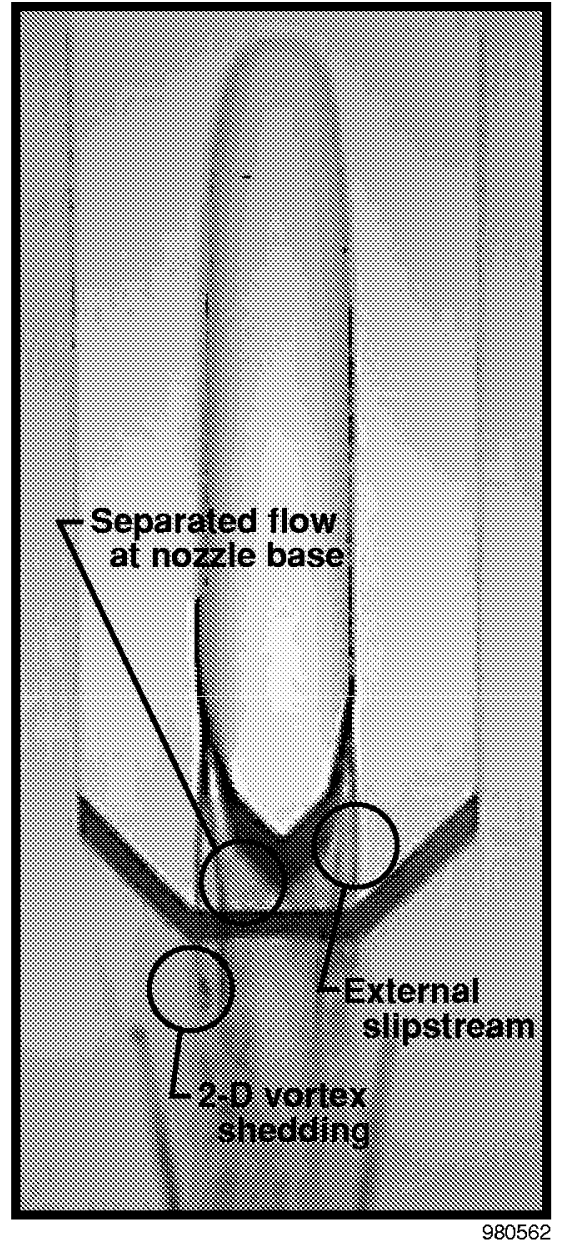

(a) Top view.

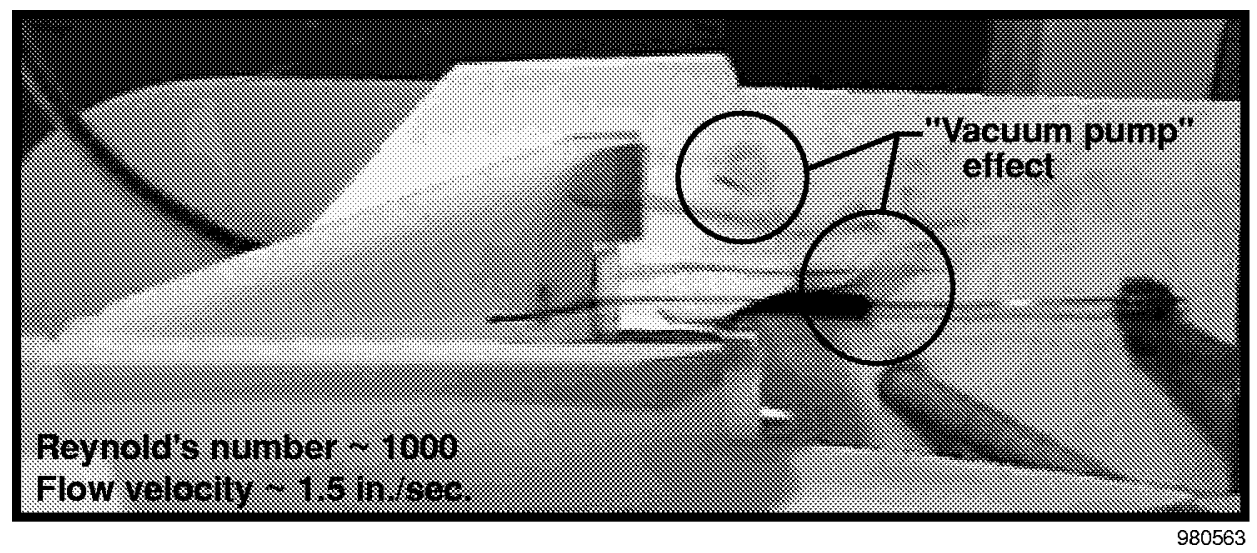

(b) Right side view.

Figure 12. Water tunnel flow visualization images for a 2.5-percent scale LASRE model. 
The above discussion leads to a possible method for base drag reduction by increasing the viscous drag acting on the forebody of the vehicle. This viscous drag increase serves to increase boundary thickness and reduces the effectiveness of the vacuum-pump acting at the base. If the boundary layer modification can be performed without additional flow separation or excessive streamline displacement along the forebody, it may be possible in some instances to decrease the drag of the entire configuration.

\section{Development of a Mathematical Model for the LASRE Drag Coefficient}

To determine whether this concept is feasible or not, a mathematical model of the LASRE base drag coefficient must first be developed which has $C_{D_{\text {fore }}}^{(1 \text { isc })}$ as a parameter and accounts for flow compressibility. As mentioned earlier, LASRE base drag data show that in the subsonic flight regime base drag remains relatively constant until the divergence Mach number of approximately 0.90 is reached. After this point compressibility effects dominate and base drag coefficient rises rapidly. Beyond Mach 1, base drag drops steadily. These trends suggest a base drag compressibility function of the form

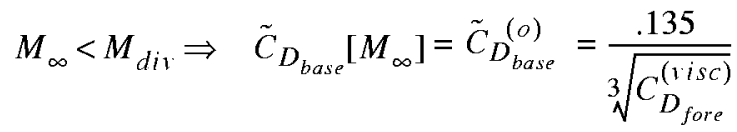

$$
\begin{aligned}
& M_{\text {div }} \leq M_{\infty}<1 \Rightarrow \tilde{C}_{D_{\text {base }}}\left[M_{\infty}\right]= \\
& \tilde{C}_{D_{\text {base }}}^{(o)} \frac{\sqrt{1-M_{\text {div }}^{2}}+\frac{1}{2} \tilde{C}_{D_{\text {base }}^{(o)}}^{(o-1}\left[\sqrt{1-M_{\text {div }}^{2}}\right]}{\sqrt{1-M_{\infty}^{2}}+\frac{1}{2} \tilde{C}_{D_{\text {base }}}^{(o)}\left[1-\sqrt{1-M_{\infty}^{2}}\right]} \\
& 1<M_{\infty}^{2} \Rightarrow \tilde{C}_{D_{\text {base }}}\left[M_{\infty}\right]= \\
& \frac{2\left[\sqrt{1-M_{\text {div }}^{2}}+\frac{1}{2} \tilde{C}_{D_{\text {base }}^{(o)}\left[1-\sqrt{1-M_{\text {div }}^{2}}\right]}\right.}{M_{\infty}^{2}}
\end{aligned}
$$

The elements of equation 12 are derived from equation 10 with modifications for compressibility defined by the Karman-Tsien correction, ${ }^{9}$ and rules of similarity for transonic flow. ${ }^{10}$ The base drag model of equation 12 is compared against measured LASRE base drag data in figure 13. For such a simple model the agreement is reasonable. Also presented in figure 13 are base drag reduction increments that would be expected (based

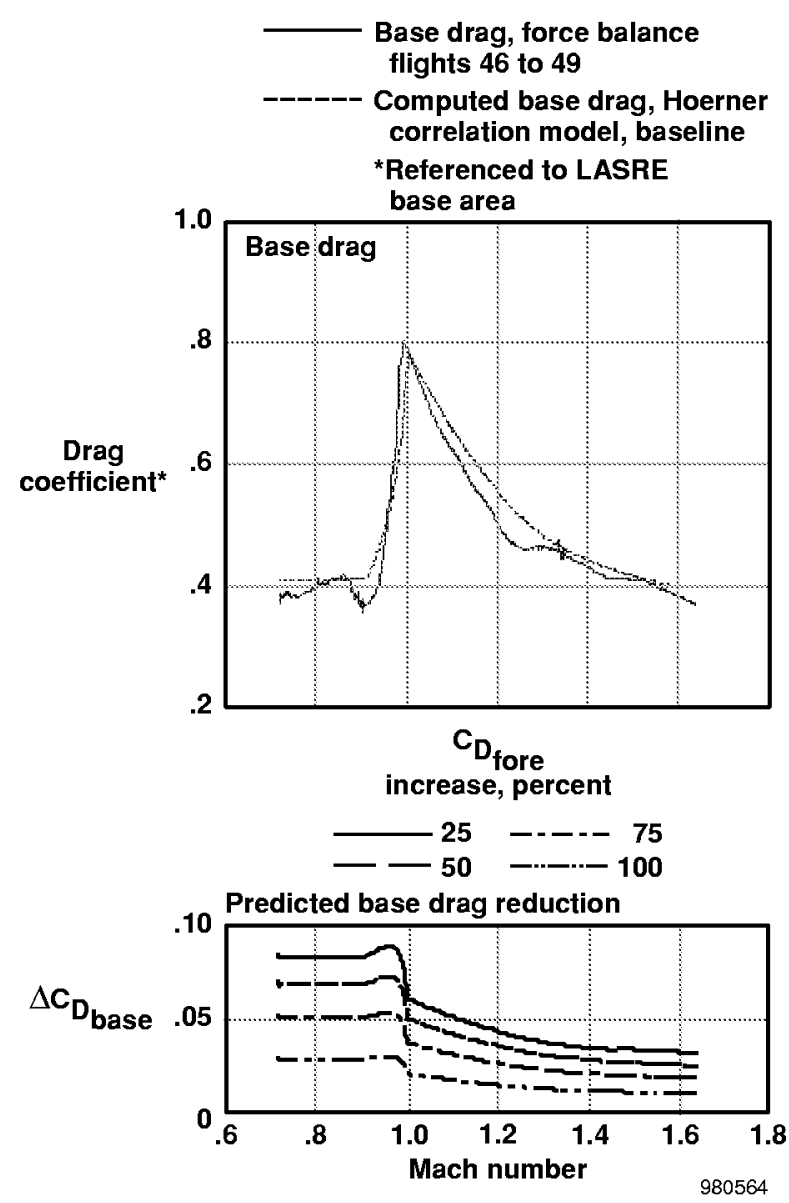

Figure 13. Comparison of the LASRE base drag coefficient with base drag prediction.

on the model of equation 12) if $C_{D_{\text {fore }}}^{(v i s c)}$ is increased by 25 percent, 50 percent, 75 percent, and 100 percent respectively.

The mathematical model of equation 12 can be extended to total drag coefficient by adding in the viscous and forebody pressure-drag terms

$$
\tilde{C}_{D_{0}}=\bar{C}_{p_{\text {fore }}}+C_{D_{\text {fore }}}^{(\text {visc })}+\tilde{C}_{D_{\text {base }}}\left[M_{\infty}\right]
$$

The analytical drag model of equation 13 is compared with the measured LASRE base drag data in figure 14. Again, for such a simple model the comparison shows good agreement.

\section{Increasing the Forebody Viscous Drag by Increasing Surface Roughness}

Clearly, one of the most convenient methods of increasing the forebody viscous drag is to add roughness 


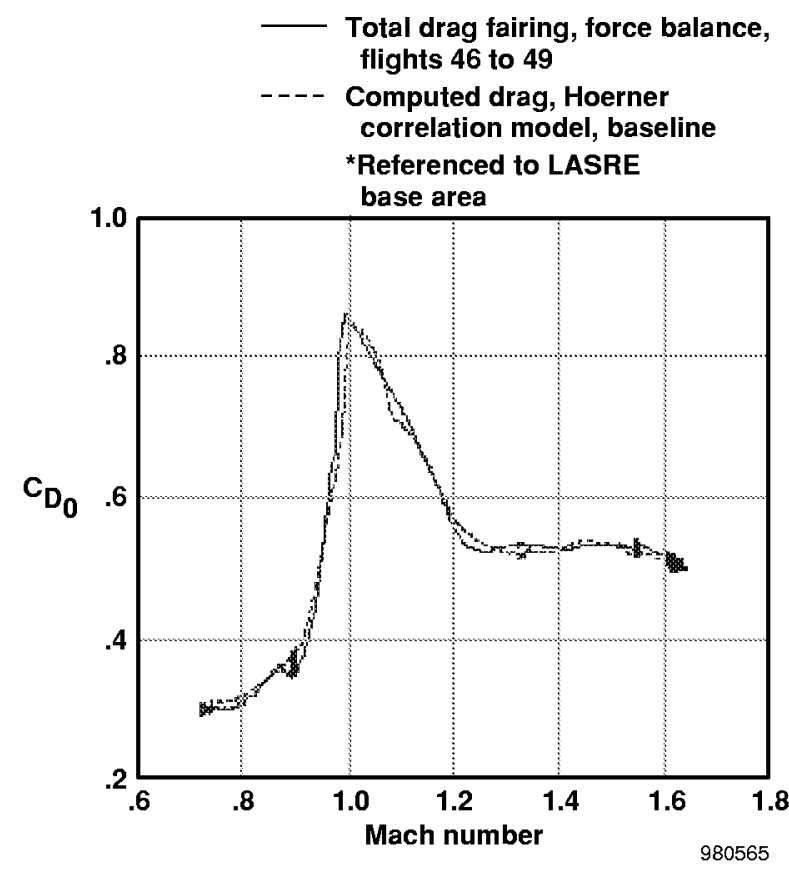

Figure 14. Comparison of the total LASRE drag coefficient with total drag prediction.

to the surface. Other methods such as using vortex generators to energize the boundary layer would probably work more effectively, but their intrusiveness into the flow precludes this method for application to the hypersonic re-entry vehicle problem. For the LASRE drag reduction experiment no. 24 Silicon Carbide (0.035 in.) grit was glued to the skin using a spray-on adhesive and the surface was sealed using a high-tensile strength white enamel paint. The resulting surface, depicted in figure 15, had an equivalent sand-grain roughness that varied between approximately $0.02 \mathrm{in}$. and $0.05 \mathrm{in}$. In an attempt to avoid inducing additional flow separation at the boat tail or along the forebody, only the flat sides of the LASRE model were gritted. The grit, depicted in figure 16 , covered an area of $32.4 \mathrm{ft}^{2}-$ approximately $1 / 3$ of the forebody wetted area.

\section{$\underline{\text { Surface Roughness Calculations }}$}

In order to predict effectiveness of the surface grit in reducing base drag, calculations of the increment in $C_{D_{\text {fore }}}^{(\text {i isc) }}$ were performed using the method of Mills and Hang. ${ }^{11,12}$ For a smooth flat plate of length $L$, the averaged skin friction coefficient is related to Reynolds number according to the empirical formula

$$
c_{f_{L}}^{(s m)} \approx \frac{0.0740}{\left[R e_{L}\right]^{1 / 5}}
$$

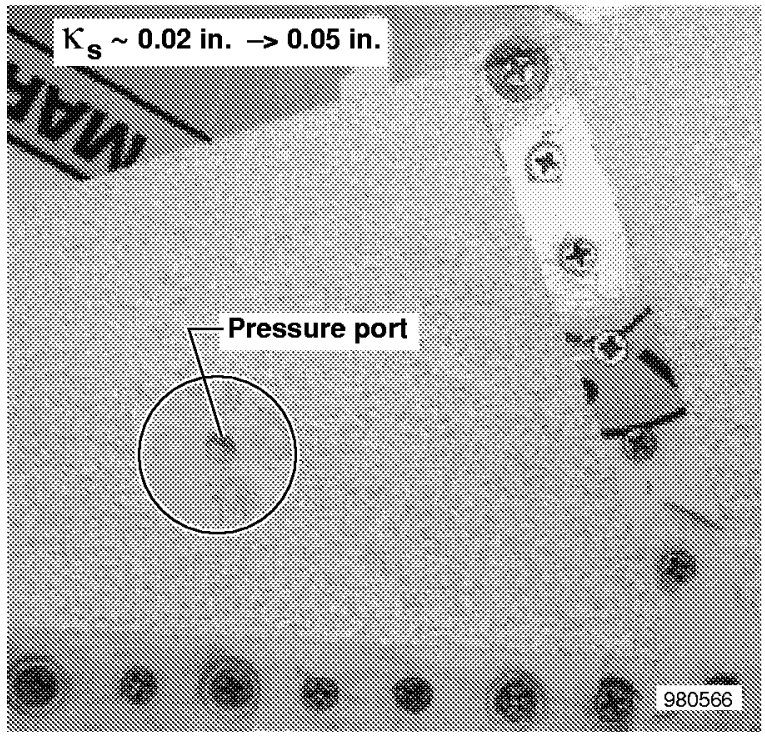

Figure 15. Close-up of LASRE grit application.

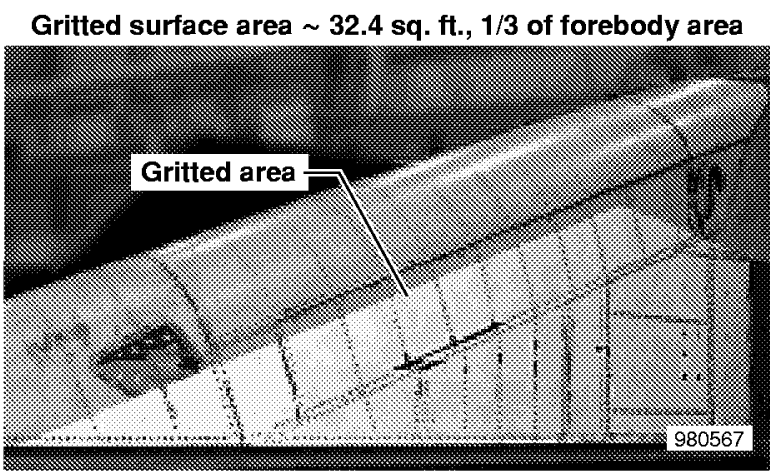

Figure 16. LASRE forebody surface grit.

When the surface of the plate is roughened, skin friction increases considerably. For a fully rough plate the empirical formula,

$$
c_{f_{L}}^{(\text {rough })}=\left[2.635+0.618 \log _{e}\left[\frac{L}{\kappa_{s}}\right]\right]^{-2.57}
$$

is a good approximation. In equation $15, \kappa_{s}$, is the equivalent sand-grain roughness of the surface extrusions. Using equations 14 and 15 , the increment in viscous forebody drag caused by added roughness is

$$
\Delta C_{D_{\text {fore }}}^{(\text {visc })}=\left[c_{f_{L}}^{(\text {rough })}-c_{f_{L}}^{(s m)}\right] \frac{A_{\text {grit }}}{A_{\text {base }}}
$$

In equation $16, A_{\text {grit }}$ is the wetted area of the surface grit, and $L$ is the length of the gritted area measured at 
the centroid. Based on an estimated range of surface roughness from $0.02 \mathrm{in}$. to $0.05 \mathrm{in}$, the calculated increase in $C_{D}^{(1 i s c)}$ ranges from 18 percent to 30 percent over the range of Mach and Reynolds numbers encountered during the LASRE flights.

\section{Flight Test Results for the Forebody Grit Experiment}

Unfortunately, the drag reduction experiment occurred so late in the LASRE program that only one flight test was conducted prior to the cancellation of the program. As a result, it was not possible to verify the flight-to-flight repeatability of the experiment. Figure 17 summarizes the flight results. The grit application did not reduce the total drag of the configuration. Nonetheless, because the base drag was reduced, results of the experiment are encouraging.

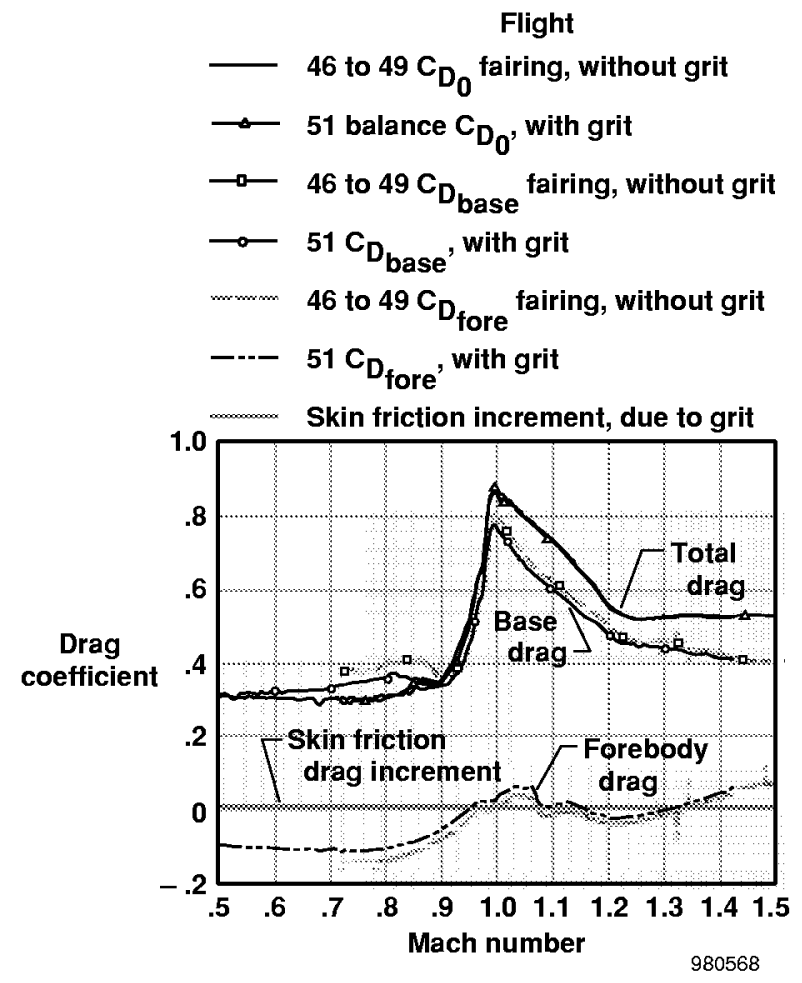

Figure 17. Effect of LASRE forebody grit: summary of drag components.

Base drag data are shown in greater detail in figure 18. Figure 18(a) shows the base drag coefficient plotted as a function of Mach number. Forebody grit reduces base drag by a peak of 15 percent in the highsubsonic flight regime. Furthermore, drag reduction benefits persist beyond Mach 1.4-well into the supersonic flight regime. Because base drag of supersonic projectiles had never been previously correlated to $C_{D_{\text {fore }}}^{(\text {visc })}$, the supersonic base drag reduction was a significant positive result. Figure 18(b) shows the measured base drag reduction compared to the base drag reduction predicted using the analytical model (equations 12,14, 15, and 16) assuming $\kappa_{s}=$ \{0.02 in., 0.05 in., and 0.10 in. $\}$. Measured drag reduction shows excellent agreement with ranges predicted by the analytical model.

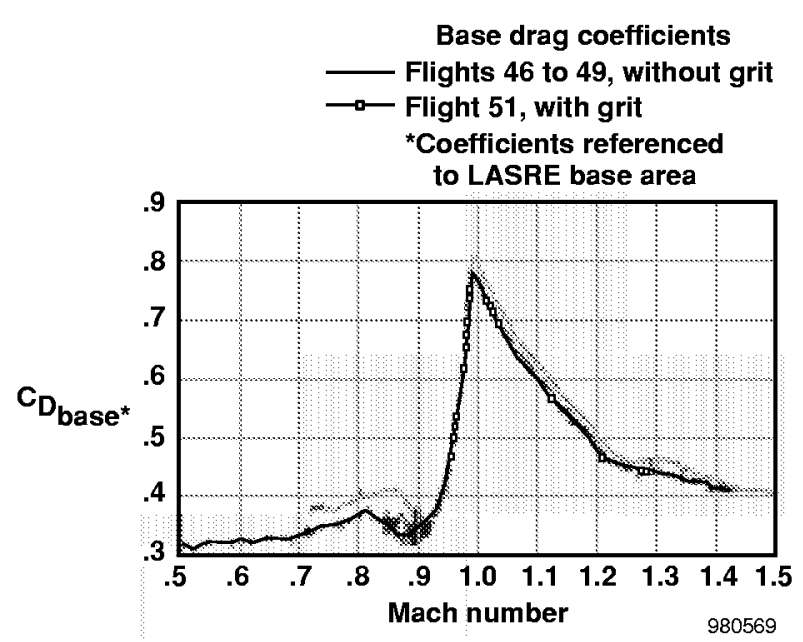

(a) Base drag.

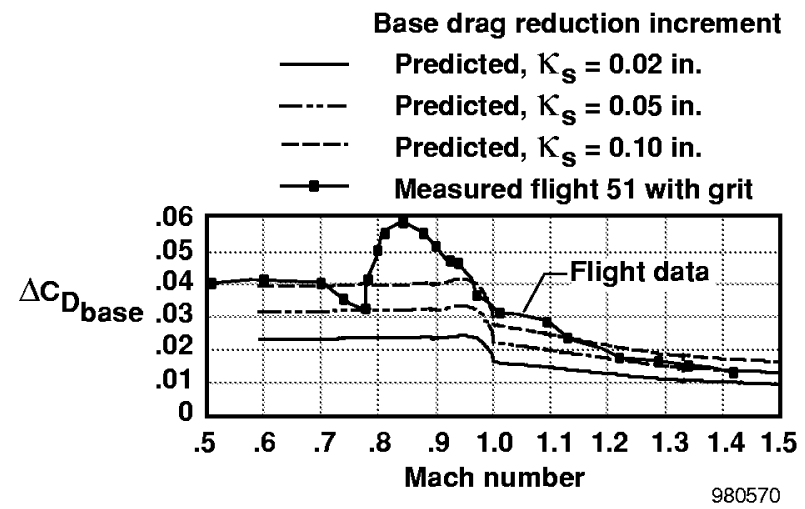

(b) Drag reduction increment.

Figure 18. Effect of forebody grit on LASRE base drag.

Overall drag of the configuration was not reduced because the forebody grit modifications caused the forebody pressures to rise. The forebody pressures along the top and cylindrical sides of the model with grit and without grit are compared in figure 19(a). The port locations for the pressures being compared are shown 
in figure 19(b). These pressure data, obtained from flight 46 (no grit) and flight 51 (with grit) at Mach 0.7, are plotted as a function of the longitudinal distance aft of the nosetip. Notice that although the pressure distribution along the model centerline was basically unchanged, the pressures on the sides of the forebody are generally higher for the grit-on data. This forebody pressure rise is further demonstrated by comparing the integrated forebody pressure drag coefficients in figure 17. When combined with added skin-drag caused by the surface roughness, the forebody pressure rise offsets the benefits gained by the base drag reduction.

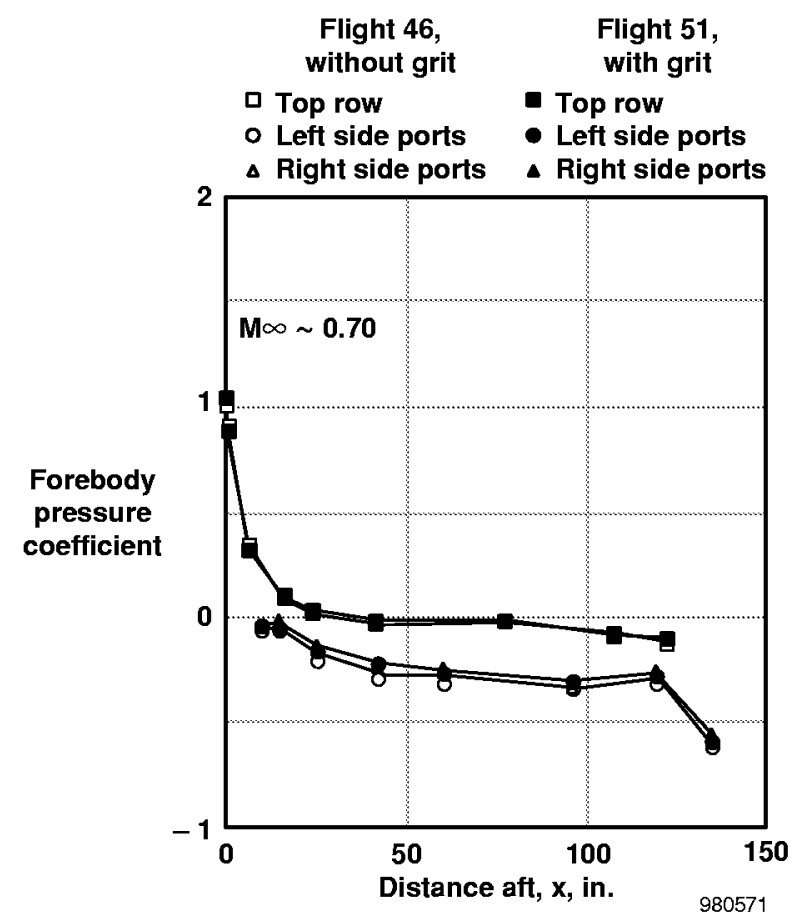

(a) Forebody pressure distribution.

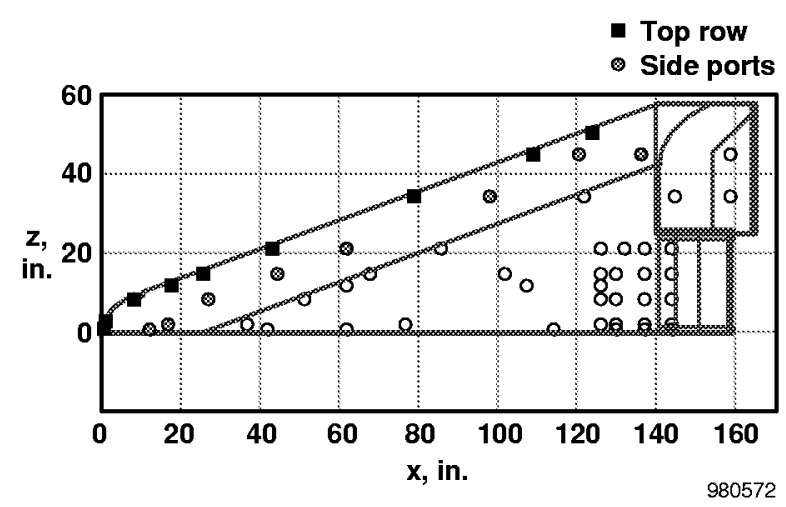

(b) Forebody pressure ports, side view.

Figure 19. Comparison of the forebody pressure distributions with and without grit.
The flight results suggest that the total drag model of equation 13 must be changed to include a possibility of increasing forebody pressure drag with surface roughness modifications. It is likely that the relationship of forebody pressure drag to viscous forebody drag will be configuration dependent. Clearly, more work needs to be performed before more definite conclusions can reached. It is also clear, however, that for configurations where base drag is a dominating factor, the forebody grit method is a potentially useful drag reduction tool.

\section{$\underline{\text { Summary and Concluding Remarks }}$}

A drag reduction experiment was conducted on the X-33 Linear Aerospike SR-71 Experiment. The flight experiment performed baseline drag measurements on a clean experiment configuration, and then attempted to reduce the base drag by increasing the forebody skin friction using added surface roughness. Preflight calculations showed that proposed surface roughness modifications would result in base drag reductions of 8 to 14 percent.

Flight results verified the effectiveness of the surface roughness technique for reducing base drag. The peak base drag reduction was approximately 15 percent. The base drag reduction also persisted well into the supersonic flight regime. Since base drag of supersonic projectiles had never been previously correlated to viscous forebody drag, the sizable supersonic base drag reduction was a significant positive result.

Unfortunately, flight test results for the rough-surface configuration did not demonstrate an overall net drag reduction. The surface grit caused a rise in forebody pressures. Coupled with increased forebody skin-drag, the forebody pressure rise offset benefits that were gained by base drag reduction. Because the flight tests did not demonstrate an overall net drag reduction, results of the drag reduction experiment are inconclusive. It is clear; however, that with some refinement, the forebody grit method provides a potentially useful drag reduction tool.

\section{$\underline{\text { References }}$}

${ }^{1}$ Saltzman, Edwin J., Charles K. Wang, and Kenneth W. Iliff, Flight-Determined Subsonic Lift and Drag Characteristics of Seven Lifting-Body and Wing-Body Reentry Vehicle Configurations With Truncated Bases, AIAA Paper 99-0383, January 1999.

${ }^{2}$ Corda, Stephen, David P. Lux, Edward T. Schneider, and Robert R. Meyer, Jr., "Blackbird Puts LASRE to the Test," Aerospace America, February 1998, pp. 25-29. 
${ }^{3}$ Otnes, Robert K. and Lauren D. Enochsen, Digital Time Series Analysis, John Wiley \& Sons, New York, 1972, pp. 237-239.

${ }^{4}$ Haering, Edward A., Jr. and Stephen A. Whitmore, FORTRAN Program for Analyzing Ground-Based Radar Data: Usage and Derivations, Version 6.2, NASA TP-3430, August 1995.

${ }^{5}$ Frieberger, W. F., ed., The International Dictionary of Applied Mathematics, D. Van Nostrand and Company, Inc., Princeton NJ, 1960, pp. 828, 829.

${ }^{6}$ Hoerner, Sighard F., Fluid-Dynamic Drag, SelfPublished Work, Library of Congress Card no. 64-19666, Washington, D.C., 1965, pp. 3-19, 3-20, 15-4, 16-5.

${ }^{7}$ Schlicting, Hermann, Boundary-Layer Theory, 7th ed., translated by Dr. J. Kestin, McGraw-Hill Publishing Co., New York, 1979, pp. 641, 642.
${ }^{8}$ Del Frate, John H., NASA Dryden Flow Visualization Facility, NASA TM-4631, May 1995.

${ }^{9}$ Freiberger, W. F., Ed., International Dictionary of Applied Mathematics, D. Van Nostrand Company Inc., Princeton, NJ, 1960, p. 506.

${ }^{10}$ Kaplan, Carl, On Similarity Rules for Transonic Flows, NACA TN-1527, Washington D.C., January 1948, pp. 8-10.

${ }^{11}$ Mills, Anthony, F. and Xu Hang, On the Skin Friction Coefficient for a fully Rough Flat Plate, J. Fluids Engineering, vol. 105, September 1983, pp. 364-365.

${ }^{12}$ Mills, Anthony F., Heat Transfer, Richard D. Irwin, Inc., Homewood, IL, 1992, pp. 282-328. 
Public reporting burden for this collection of information is estimated to average 1 hour per response, including the time for reviewing instructions, searching existing data sources, gathering and maintaining the data needed, and completing and reviewing the collection of information. Send comments regarding this burden estimate or any other aspect of this collection of information, including suggestions for reducing this burden, to Washington Headquarters Services, Directorate for Information Operations and Reports, 1215 Jefferson Davis Highway, Suite 1204, Arlington, VA 22202-4302, and to the Office of Management and Budget, Paperwork Reduction Project (0704-0188), Washington, DC 20503.

1. AGENCY USE ONLY (Leave blank)

\section{REPORT DATE}

March 1999

\section{REPORT TYPE AND DATES COVERED}

Technical Memorandum

4. TITLE AND SUBTITLE

A Base Drag Reduction Experiment on the X-33 Linear Aerospike SR-71

Experiment (LASRE) Flight Program

6. AUTHOR(S)

WU 242-33-02-00-23-00-T15

Stephen A. Whitmore and Timothy R. Moes

7. PERFORMING ORGANIZATION NAME(S) AND ADDRESS(ES)

NASA Dryden Flight Research Center

P.O. Box 273

Edwards, California 93523-0273

8. PERFORMING ORGANIZATION

REPORT NUMBER

H-2333

9. SPONSORING/MONITORING AGENCY NAME(S) AND ADDRESS(ES)

10. SPONSORING/MONITORING AGENCY REPORT NUMBER

National Aeronautics and Space Administration

Washington, DC 20546-0001

NASA/TM-1999-206575

11. SUPPLEMENTARY NOTES

Presented at the 37th AIAA Aerospace Sciences Meeting and Exhibit, Reno, Nevada, January 11-14, 1999 as AIAA-99-0277.

12a. DISTRIBUTION/AVAILABILITY STATEMENT

12b. DISTRIBUTION CODE

Unclassified-Unlimited

Subject Category 05

13. ABSTRACT (Maximum 200 words)

Drag reduction tests were conducted on the LASRE/ X-33 flight experiment. The LASRE experiment is a flight test of a roughly 20 -percent scale model of an X-33 forebody with a single aerospike engine at the rear. The experiment apparatus is mounted on top of an SR-71 aircraft. This paper suggests a method for reducing base drag by adding surface roughness along the forebody. Calculations show a potential for base drag reductions of 8 to 14 percent. Flight results corroborate the base drag reduction, with actual reductions of 15 percent in the high-subsonic flight regime. An unexpected result of this experiment is that drag benefits were shown to persist well into the supersonic flight regime. Flight results show no overall net drag reduction. Applied surface roughness causes forebody pressures to rise and offset base drag reductions. Apparently the grit displaced streamlines outward, causing forebody compression. Results of the LASRE drag experiments are inconclusive and more work is needed. Clearly, however, the forebody grit application works as a viable drag reduction tool.

14. SUBJECT TERMS

Aerospike engine, Base drag, Skin friction

OF REPORT

Unclassified

NSN 7540-01-280-5500
18. SECURITY CLASSIFICATION OF THIS PAGE

Unclassified
15. NUMBER OF PAGES

22

16. PRICE CODE

A03

20. LIMITATION OF ABSTRACT

Unlimited

\section{Unclassified}

